\title{
Evaluating the level of sustainability of privately managed forest in Bogor, Indonesia
}

\author{
TATAN SUKWIKA ${ }^{1, \varphi}$, DUDUNG DARUSMAN ${ }^{2}$, CECEP KUSMANA $^{1,3}$, DODIK RIDHO NURROCHMAT $^{2}$ \\ ${ }^{1}$ Nature Resources and Environmental Management Program, Bogor Agricultural University. Kampus IPB Baranangsiang, 16144 Bogor, West Java, \\ Indonesia Tel./Fax. +62 2518332779 , "email: tatan.swk@gmail.com \\ ${ }^{2}$ Department of Forest Management, Faculty of Forestry, Bogor Agricultural University. Kampus IPB Dramaga, Jl. Lingkar Akademik, Bogor 16680, \\ West Java, Indonesia. PO Box 168, Tel.: +62 251-8621244 Fax.: +62 251-8621244 \\ ${ }^{3}$ Department of Silviculture, Faculty of Forestry, Bogor Agricultural University. Kampus IPB Dramaga, Jl. Lingkar Akademik, Bogor 16680, West Java, \\ Indonesia. PO Box 168, Tel.: +62 251-8626806, Fax.: +62 251-8626886
}

Manuscript received: 6 October 2015. Revision accepted: 27 March 2016

\begin{abstract}
Sukwika T, Darusman D, Kusmana C, Nurrochmad DR. 2016. Evaluating the level of sustainability of privately managed forest in Bogor, Indonesia. Biodiversitas 17: 241-248. This study discusses the sustainability of small scale private forest in Bogor, Indonesia. It aims to determine the dimensions of sustainable private-forest and analyzing the sustainability index of privately managed forest. This study uses multidimensional scaling (MDS) to analyze the dimensions of sustainability, ranked from 0 (the lowest) to 10 (the highest), along with the support of Rap-Pforest, in order to assess the level of similarity and dissimilarity for each dimension. Using this scale from the sustainability index, this study estimates the level of sustainability of each dimension. After measuring each attribute's level of ordination RMS change on the X axis, we estimate the error's effect using Monte Carlo analysis. This study shows that the ecology as well as legal and institutional dimensions are moderately sustainable, with a sustainability index of $53.66 \%$ and $52.48 \%$. However, the dimensions of economy, socio-culture, as well as accessibility and technology are less sustainable, with an index measurement of $41.62 \%, 47.02 \%$ and $47.56 \%$, respectively. Based on those five sustainability dimensions, this study concludes that in average the level of sustainability of private-forest management in the Bogor is not sustainable (48.47\%). We recommend that to improve the sustainability of small scale private forest management in Bogor, multiple stakeholders should be involved to development the most appropriate policy options.
\end{abstract}

Keywords Bogor, Monte Carlo analysis, private-forest, RMS, small scale forestry, sustainability index

\section{INTRODUCTION}

The total area of private-forests in Bogor is estimated to be 16,945 hectares, much less than the 74,521 acres of state state-owned forest (Distanhut 2014). According to the Distanhut $(2008,2014)$, the area of state forest of Bogor in 2008 was 79,437 hectares and decreased to 74,521 hectares in 2014. Meanwhile, the area of private-forest in Bogor was 11,379 hectares in 2008 , and increased to 16,945 hectares in 2012.Increasing private-forest area does not automatically deliver economic and social benefits to proximate communities. In Bogor, people living around forests are still vulnerable to poverty. Distanhut (2012) reports that people who live around the forest are mostly poor, due to their reliance on (small-scale) farming and onfarm employment for living. On average, these households own between 0.25 and 1 hectares, including self-ownership and co-ownership (Andayani 2003; Birgantoro and Nurrochmat 2007; Kigenyi 2007; Plencovich 2014).The major contributors to continued poverty within these smallscale farming communities include low levels of technology and low market price. There is no exact planting time and harvesting schedule for private-forests. The basic capacity of extension workers, low level of access to information, and poor infrastructure also contribute to continued poverty in this area. All of these problems combine to contribute to stakeholders' low awareness on the sustainability issues (Darusman and Hardjanto 2006; Gunarso et al. 2007a).

Sustainable forest management is a way of using and caring for forests in order to maintain environmental, social, and economic values and benefits over time. "As a dynamic and evolving concept, it aims to maintain and enhance the economic, social and environmental value of all types of forests, for the benefit of present and future generations" (UN 2008; FAO 2010). Sustainable forest management is characterized by: (i) extent of forest resources; (ii) forest biological diversity; (iii) forest health and vitality; (iv) productive functions of forest resources; (v) protective functions of forest resources; (vi) socioeconomic functions of forests; and (vii) legal, policy, and institutional framework and infrastructure (Prabhu et al. 1998; Levang 2002; Clarke 2006; Gunarso et al. 2007b; UN 2008; Nasi and Frost 2009; SCBD 2009; Kant 2010; Kant et al. 2013; Nurrochmat and Abdulah 2014).

Private-forest owners play a key role in sustaining forest ecosystems, enhancing rural development, and supplying resources to markets. Nevertheless, a significant lack of knowledge remains regarding private forest ownership (Schmithüsen and Hirsch 2010; Kant et al. 2013). Private-forest areas have an important role in the economic development in Bogor, but poor forest 
management has caused environmental damage. Factors causing deforestation in private-forest areas include activities performed by the inhabitants, increased population, and land conversion (Angelsen 1999; Kant and Lee 2004; Darusman and Wijayanto 2007; Gunarso et al. 2007a; Chakravarty et al. 2012).

In addition to poverty, other issues related to the private-forest degradation include relatively low levels of land ownership, low education, and lack of skills outside the agriculture and forestry sectors (Kusmana 2011; Zhang and Pearse 2011; Kant et al. 2013). This study discusses the obstacles that frequently prevent the sustainable management of private forests, including physical capital (Febriani et al. 2012), market incentives and private forest ownership (Kigenyi 2007; Wijayanto 2007; Kusmana 2011; Suryawati et al. 2011; Wolosin et al. 2012; Silas, 2014), and the contribution of market demand for timber products (Mutaqin 2008; Kant 2003, 2004; Kant and Berry 2005; Agrawal et al. 2013; Wollenberg 2014).

This study aims to assess the level of sustainability of private-forest in Bogor based on five key dimensions: ecology, economy, socio-culture, legality and institutional factors, as well as infrastructure and technology. It analyzes these dimensions using MDS (Multidimensional Scaling); to ascertain the sustainability index of privately managed forests in Bogor.

\section{MATERIALS AND METHODS}

This study was conducted within the District of Bogor, West Java Province, Indonesia from April 2015 to August 2015. Bogor has a total area of 298 thousand hectares, with $14.32 \%$ forest cover. This area consists of protected and production forest. Protected forest area is mostly located in the upland areas, and it serves as a water catchment area, while the production forest areas spread from lowlands to uplands.

\section{Data collection}

To detect the level of sustainability we use Multidimensional Scaling (MDS). MDS is a method of multivariate statistical analysis that determines the position of a concept based on similarity or dissimilarity to another principle or concept (Borg and Groenen; 1997; Groenen and van de Velden 2004; Groenen and Terada 2015). Yaoung (2009) indicates that MDS is a data analysis technique which displays conceptual similarity in the form of geometric images based on the Euclidean distance between concepts, based on questionnaire responses. This analysis occurs through several stages. (i) The determination of the private-forest sustainability dimensions of the Bogor District that includes five dimensions: ecological, economic, socio-cultural, legal and institutional, as well as infrastructure and technology. Each dimension is then measured using attributes scores (Pitcher and Preiksho 2001). (ii) The valuation of each attribute in an ordinal scale is based on sustainability criteria of each dimension. Expert respondents used scientific judgment to determine the attribute of each dimension. Experts scored the attributes of each dimension between 0 and 10 (Pitcher et al. 2013). (iii) Finally, this method is used to calculate the sustainability index and analyze the status of sustainability.

Through the MDS method, the position of the point of sustainability can be visualized through the horizontal and vertical axis. With rotation, the position of the point can be visualized on a horizontal axis with a rated value of the sustainability index score. Score estimation of each dimension is expressed from the lowest score (unsustainable) $0 \%$ to the best (sustainable) $100 \%$ (see Figure 1), and grouped into four categories namely; 0$25.00 \%$ (bad or unsustainable), 25.01-50.00\% (less sustainable), 50.01-75.00\% (fairly sustainable), and 75.01$100.00 \%$ (highly sustainable). The sustainability index includes the value of each dimension to describe the total level of sustainability (Pitcher 1999). Table 1 illustrates the index and rankings.

The index value of sustainability of each dimension can be visualized at the same time using a kite diagram. The symmetrical of kite diagram is determined by the sustainability index of each dimension (economic, social and culture, ecological, legal and institutional as well as infrastructure and technology). Further, kite diagrams display the value of sustainability index for each dimension.

Sensitivity analysis provides further information onthe MDS analysis and the private-forest sustainability index. Sensitivity analysis indicates which attributes contribute to the resources sustainability value. This sensitivity analysis used the attribute leveraging to assess the change in the analytical output from MDS. The effect of each attribute is observed in the change of root mean square (RMS), particularly on the $\mathrm{x}$-axis for resources sustainability scale (Kavanagh 2001). The RMS formula is as follows:

$$
R M S=\sqrt{\left[\frac{\sum_{i=1}^{n}\{V f(i, 1)-V f(, 1)\}^{2}}{n}\right]}
$$

$\mathrm{V} f(i 1)=$ Value of MDS output (after rotation and flipping). $\mathrm{V} f(, 1)=$ Median of MDS output in column-1.

Table 1.Sustainability status category of privately managed forest in Bogor District, Indonesia (Fauzi and Anna 2005)

\begin{tabular}{ll}
\hline Index value & Category \\
\hline $00.00-25.00$ & Poor (not continuous) \\
$25.01-50.00$ & Less (less sustainable) \\
$50.01-75.00$ & Enough (quite sustainable) \\
$75.01-100.00$ & Good (very sustainable) \\
\hline
\end{tabular}

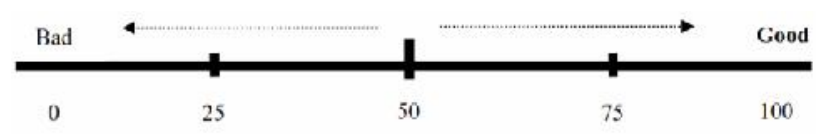

Figure 1. Rate value of sustainability index score of $0 \%$ (bad) to $100 \%$ (good) 
Monte Carlo analysis evaluates the error effect by assessing the ordination. The effect of error can be caused by various conditions, including error in scoring due to imperfect understanding of the attribute or field condition, score variation from different opinion or valuation of the researcher, repeated MDS analytical processes, error in data input or missing data, iteration stability, and high stress value (acceptable stress value should be <25\%) (Kavanagh and Pitcher 2004; Fauzi and Anna 2002).

Goodness of fit in MDS is indicated by the amount of SStress value, calculated based on the value of $S$ and $R^{2}$. Lower stress values indicate a good fit while higher $\mathrm{S}$ values indicate the opposite. In the approach with RapPforest, a good model contains a stress value less than 0.25 or $S<0.25$ (Fauzi and Anna 2005) and relatively better fitting models have an $\mathrm{R}^{2}$ that approaches 1.0.

\section{RESULTS AND DISCUSSION}

\section{Ecological dimension}

Analysis from Rap-Pforest (Rapfish modification) shows that the sustainability index for the ecological dimension is 53.66 (Figure 2). This indicates that the ecological dimension is "quite sustainable". The main factors that contribute to the sustainability of this dimension include the potential of efficient land use by proximate communities $(\mathrm{RMS}=2.73)$, critical land conservation $(\mathrm{RMS}=2.20)$ and infrequent land conversion (RMS=2.33). These attributes contained the greatest values within the ecological dimension.

\section{Economic dimension}

This study indicates that the economic dimension has a value of 41.62 above the midpoint between unsustainable and sustainable (Figure 3). Thus, the economic dimension should be considered "less sustainable" based on the sustainability index value. Of the 17 attributes within the economic dimension, the results show wood productivity (RMS=2.37), incentive for farmer price of timber (RMS=1.61), monthly income of farmer $(\mathrm{RMS}=1.66)$ and middlemen (broker) (RMS=1.71) are the attributes that contribute most to the economic dimension.

Timber prices for private-forests are often determined by middlemen (tengkulak) and debt bondage (ijon). This represents a series of transactions that are not profitable for farmers.

\section{Socio-culture dimension}

This study indicates that the sustainability index on socio-culture dimension is 47.02 (Figure 4), and is thus considered "less sustainable". This score is driven by the inability for the forestry sector to sufficiently employ available human resources, and the related high levels of poverty. There are three attributes that are the most sensitive and should get the attention to increase the sustainability value of social and culture dimension, including: farmer participation for adding value $(\mathrm{RMS}=1.65)$, poverty $(\mathrm{RMS}=1.24)$, and employment opportunity (RMS=1.27).
Promoting community participation, increasing employment opportunities within the local forestry sector, and reducing poverty can increase the sustainability of the socio-culture dimension. Specifically, funding assistance and post-capture processing training can provide added value to timber. Increasing the added value from timber can directly increase farmer income, and reduce poverty within forest proximate communities.

\section{Legal and institutional dimension}

Figure 5 shows that legal and institutional dimension has a value of 52.48, indicating an index score of "quite sustainable". Of the 11 attributes on the legal and institutional dimension, the most sensitive attributes include microfinance institution $(\mathrm{RMS}=2.50)$, the number of forestry extension/counseling (RMS=2.59), government elucidation institution (RMS=2.32), and forestry extension/ counseling programs (RMS=2.67).

Of the 11 attributes that comprise the Legal and Institutional dimension, the number of forestry extension/ counseling of the private-forest management and forestry extension/counseling programs in the Bogor District are the most sensitive. In order to enhance the sustainability index, local government can increase the number of forestry extension organizations and/or agents in order to disseminate and implement more effective government forestry programs.

\section{Accessibility and technology dimension}

The value of sustainability index of the accessibility and technology dimension based on the Rap-Pforest analysis is 49.77 (Figure 6), categorized as "less sustainable". Leverage analysis indicates that of the 11 attributes in this dimension, four attributes contributed the most to the accessibility and technology dimension: the support of road infrastructure to public services (RMS=2.28), market information access (RMS=2.88), post-harvest processing of wood $(\mathrm{RMS}=3.13)$ and standardization of felling of trees (RMS $=2.24)$.

Inter-village transport is limited. It depends upon the use of a private vehicle (commonly a motorbike), and roads are occasionally closed because of landslides or a lack of maintenance. In addition, knowledge of and access to information on post-harvest technology, important for ensuring the quality of timber and appropriate prices, is limited within communities that own private forests.

The overall result of the leverage analysis for the five dimensions generated 18 attributes that have substantial impacts on the management of sustainable private forests (Table 2). These values were selected based on their RMS (root mean square) value. These leverage factors are important for developing a model of sustainable private forest management policy.

\section{Test of validity}

The Monte Carlo test of validity indicates that the differences of average value of the two analyses are $0.60 \%$. This means that the MDS analysis model is adequate for estimating the sustainability index value of the privateforest in the Bogor District. The small validity 


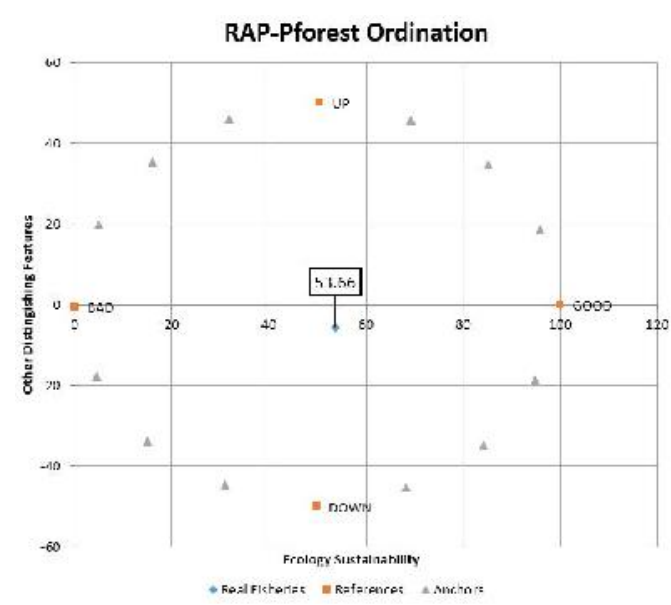

Figure 2. Ecological sustainability index in Bogor District, Indonesia

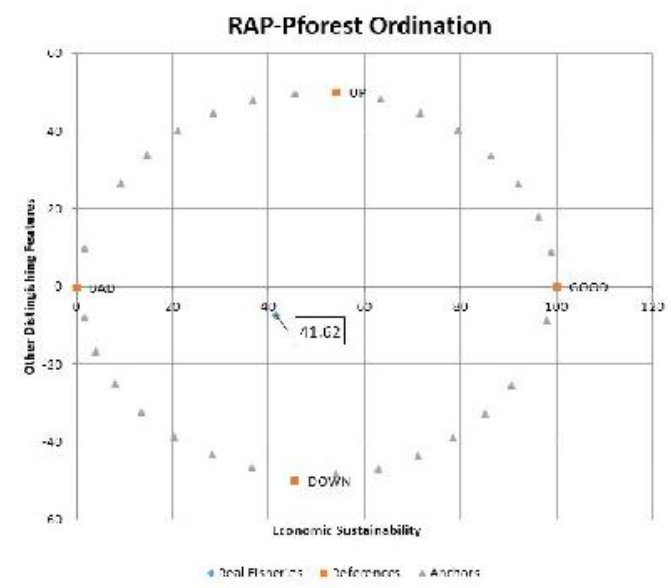

Figure 3. Economic sustainability index in Bogor District, Indonesia

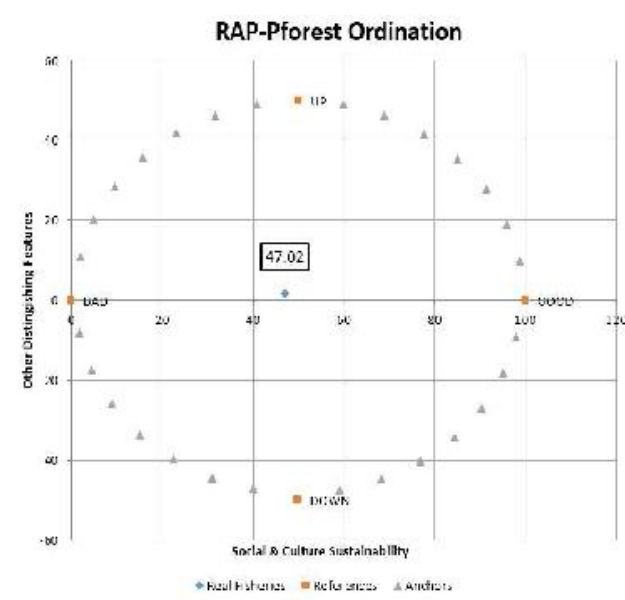

Figure 4. Social and culture sustainability index in Bogor District, Indonesia

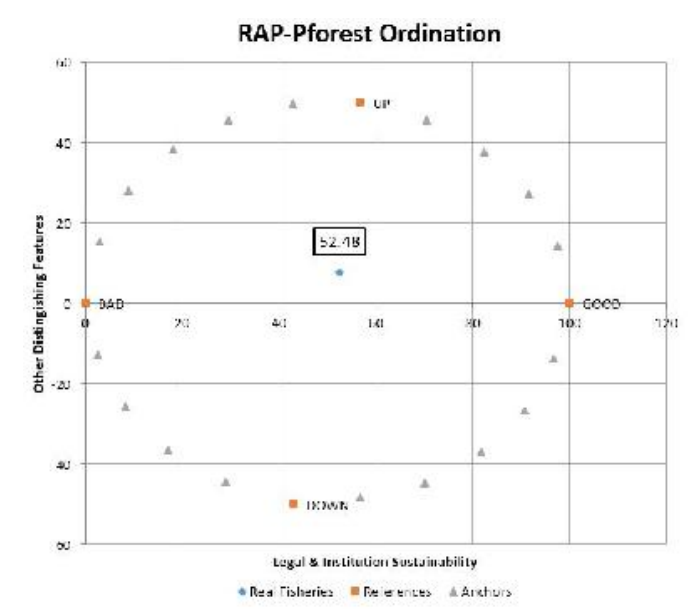

Figure 5. Legal and institutional sustainability index in Bogor District, Indonesia

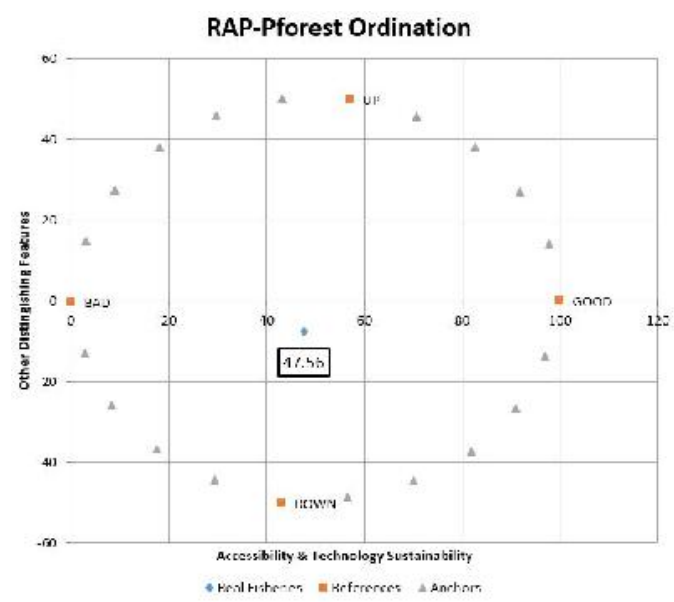

Figure 6. Accessibility and technology sustainability index in Bogor District, Indonesia

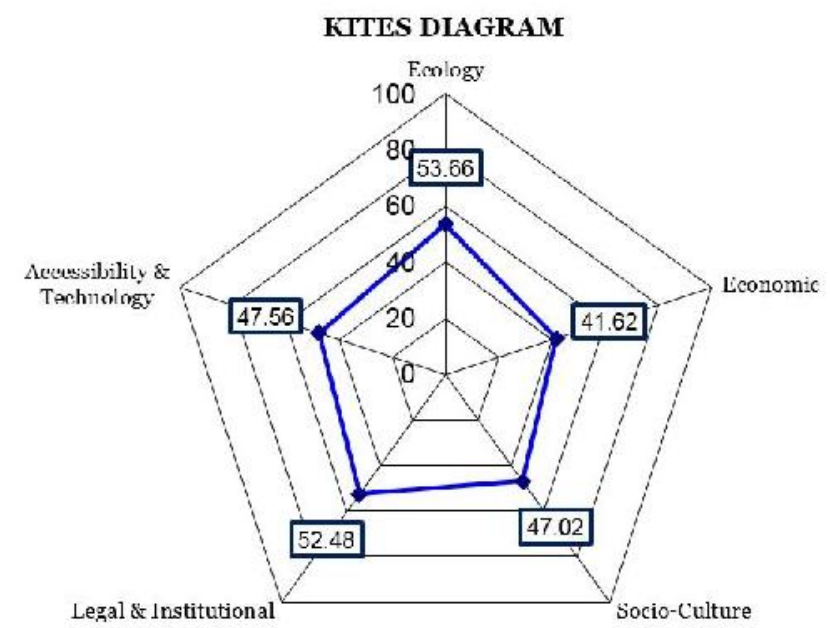

Figure 7. Kites diagram of the privately managed forest in Bogor District, Indonesia based on Rap-Pforest analysis result 
Table 2. Sensitive attributes of sustainability of privately managed forest in Bogor District, Indonesia

\begin{tabular}{|c|c|c|}
\hline Dimension & Attribute & RMS \\
\hline \multirow[t]{3}{*}{ Ecology } & 1. Land using efficiency by community & 2.73 \\
\hline & 2. Critical land conservation & 2.20 \\
\hline & 3. Land conversion & 2.33 \\
\hline \multirow[t]{4}{*}{ Economic } & 4. Wood productivity & 2.37 \\
\hline & 5. Incentive for farmer price & 1.61 \\
\hline & 6. Monthly income of farmer & 1.66 \\
\hline & 7. Broker (middlemen) & 1.71 \\
\hline \multirow[t]{3}{*}{ Socio-culture } & 8. Farmer participation for adding value & 1,65 \\
\hline & 9. Poverty (farm household) & 1,24 \\
\hline & 10. Employment opportunity & 1.27 \\
\hline \multirow[t]{4}{*}{ Legal and institutional } & 11. Microfinance institution & 2.50 \\
\hline & 12. The number of forestry extension/counseling & 2.59 \\
\hline & 13. Government extension/counseling institution & 2.32 \\
\hline & 14. Forestry extension/counseling programs & 2.67 \\
\hline \multirow{4}{*}{ Accessibility and technology } & 15. Road infrastructure to public services & 2.28 \\
\hline & 16. Market information access & 2.88 \\
\hline & 17. Post-harvest processing of wood & 3.13 \\
\hline & 18. Standardization of felling of trees & 2.24 \\
\hline
\end{tabular}

Table 3. Difference of sustainability index value of Rap-Pforest in Bogor District, Indonesia and the Monte Carlo analysis

\begin{tabular}{lcccc}
\hline \multirow{2}{*}{ Dimension } & \multicolumn{3}{c}{ Sustainability Index Value (\%) } \\
\cline { 2 - 5 } & MDS & Monte Carlo (MC) & Difference (MDS-MC) & Difference (MDS-MC) \% \\
\hline Ecology & 53.66 & 53.69 & 0.64 & 1.21 \\
Economy & 41.62 & 41.43 & 0.19 & 0.46 \\
Socio-culture & 47.02 & 46.67 & 0.35 & 1.75 \\
Legal and institutional & 52.48 & 52.26 & 0.22 & 0.42 \\
Accessibility and technology & 47.56 & 47.52 & 0.04 & 0.08 \\
Average & 48.47 & 48.18 & 0.29 & 0.60 \\
\hline
\end{tabular}

Table 4. Stress value and the value of determination $\left(\mathrm{R}^{2}\right)$ Rap-Pforest result in Bogor District, Indonesia

\begin{tabular}{|c|c|c|c|c|c|}
\hline \multirow[b]{2}{*}{ Parameter } & \multicolumn{5}{|c|}{ Dimension of } \\
\hline & Ecology & Economy & Socio-culture & $\begin{array}{c}\text { Legal and } \\
\text { institutional }\end{array}$ & $\begin{array}{c}\text { Accessibility and } \\
\text { technology }\end{array}$ \\
\hline Value of Index ${ }^{*}$ & 53.66 & 41.62 & 47.02 & 52.48 & 47.56 \\
\hline Value of Stress ${ }^{* *}$ & 0.156 & 0.136 & 0.143 & 0.142 & 0.140 \\
\hline Value of $\mathrm{R}^{2 * * *}$ & 94.48 & 95.40 & 95.13 & 95.11 & 95.23 \\
\hline Number of Iteration & 2.00 & 2.00 & 2.00 & 2.00 & 2.00 \\
\hline
\end{tabular}

value indicates the error from data acquisition and analysis is minimal, and does not jeopardize the results from this study (Fauzi et al. 2005).

Monte Carlo analysis can also be used as simulation methods to evaluate the impact of random error on the statistical analysis conducted for all dimensions (Pitcher and Preiksho 2001; Kavanagh and Pitcher 2004). Table 3 contains the results from MDS and Monte Carlo Analysis.

\section{Test of accuracy}

The accuracy test of the MDS analysis (good and fit) obtained the coefficient of determination $\left(R^{2}\right)$ between $94.48 \%-95.40 \%$. Since this value is larger than $80 \%$, it is categorized as both good and fit (Kavanagh 2001). The stress value of 0.136 to 0.156 , with a difference of 0.02 , indicates the results obtained from MDS analysis is highly accurate (good and fit), and sufficient for assessing the private-forest sustainability index in Bogor, West Java (Fisheries 1999). Table 4 contains the stress value of the determination coefficient from the Rap-Pforest analysis.

\section{Discussion}

Based on the analysis of the sustainability index value for the five dimensions, Figure 7 illustrates the kites diagram from privately managed forests in the district of Bogor. Figure 7 demonstrates that economic, socio-culture, 
and accessibility and technology are "less sustainable", amounting to $41.62 \%, 47.02 \%$ and $47.56 \%$, respectively. Two dimensions ecology as well as legal and institutional, are "quite sustainable", with sustainability indices of $53.66 \%$ and $52.48 \%$, respectively. Based on the five sustainability indexes (see Table 3), the level of sustainability of privately managed forest in the Bogor is, overall, "less sustainable" (48.47\%).

These five dimensions were calculated from expert opinion scores and bundled in sustainability dimensions. Within the dimension of ecology there are three leverage variables, one of which is efficiency of community-based land utilization (RMS value 2.73). Experts agree that farmers' behavior in land utilizing was very exploitative and less-organized (for instance, farmers used sporadic distances to cultivate agroforestry and inter-cropping). In the long term, this behavior can result in negative externalities for the land and ecosystem services surrounding forest areas. These negative ecological externalities should be considered in tandem with the poverty of farmers near forest areas (Guntoro 2011; Ingram et al. 2012).

Poverty and ecological degradation cannot be separated. Ecological degradation causes poverty, and poverty can increase ecological degradation (DeClerck 2006). In community forests, human-environment interactions are many (Abel and Stepp 2003; De Sherbinin et al. 2007). Thus, integrated and comprehensive poverty alleviation should not overlook ecological aspects. Farmers are not independent from forest ecosystems, as these systems provide environmental-based goods and services. Even welfare delivered mostly through markets often comes from ecosystem services (Wildenberg 2005; Schneider et al. 2010).

Within economic dimensions, the poverty of privateforest farmers (RMS value 1.24) was the main focus for the experts, as farmers' expenditures were three times that of their monthly income. In order to cover the monthly needs, the farmers rely on middlemen/broker (tengkulak) to buy their timber and non-timber production. Farmers sold sengon (Albizia falcataria) and kayu afrika (Maesopsis eminii). Farmers often sold these timber products at prices far below standard market valuation. Despite the profitability of timber markets elsewhere in Indonesia, the timber market in Bogor does not significantly contribute to the regional economy. [Data of BPS (2015) noted gross domestic product/GDP's forestry $=1.89 \%$ ]. The availability of timber product in Bogor is purported to meet only local and regional needs. Based on information from interviews with key informants that despite this trend, there are remained many opportunities within the forestry sector. However, many who are able to work within this sector prefer manufacturing jobs or unemployment. Thus, private forests are managed mostly by the elderly. These results in a gap between their monthly expenses and income, and it contribute to the persistence of regional poverty. This is then also a concern in social dimension.

Experts agree that, for the accessibility and technology dimension, farmers do not use harvesting or processing technology, although they have some access to this technology (RMS value 2.24). According to data from this study, private forest managers employed brokers' services, such as logging, skidding, and transportation to the wood processing industry. The strong role of brokers has a negative impact on farmer's welfare, due to the reduction of timber prices (Nurrochmat et al. 2014). Despite promoting the community's involvement or participation in forest management, as well as reducing the role of broker (tengkulak), a private forestry policy system is necessary to develop the region's timber-based management and processing through an integrated system that involves community (society) and business (Sahide et al. 2015). Meanwhile, within the legal and institutional dimension, experts noted the lack of availability of extension workers (RMS value 2.59), as well as the uncertainty of their counseling schedule. The presence of extension workers is promotes the importance of ensuring economic, social and ecological sustainability.

The limited capacity for private forest farmers to implement planting and logging standards, and the current lack of community-level institution, have rendered privateforest utilization less successful and less sustainable. Meanwhile, the lack of available field officers to support farmers decreases the productivity private forests while the limited availability knowledge about processing technology, combined with minimal market access, have contributed to unfair timber pricing at the expense of farmer incomes.

Based on the five sustainability dimension that have been analyzed here, the private-forest management in the Bogor is "less sustainable", with the average sustainability index of $48.47<50$. Focusing on the 18 sensitive attributes of sustainability of privately managed forest in Bogor (see Table 2), public and/or private programs should begin by monitoring the role of timber brokers.

To increase the sustainability index within the economic dimension, government and/or stakeholder intervention is needed to support a standard pricing for timber products, fertilizer, and insecticide. Further assistance to improve the empowerment of farmers' groups through a more productive planting program, farmers' timber-product price stabilization through a comprehensive partnership program on timber-product industrialization could also assist in the improvement of economic sustainability from private forests in Bogor.

To ensure sustainability of private forests in Bogor, it is necessary to (i) involve all stakeholders of society, businessmen and government in the management of private-forest resources in the Bogor, (ii) reduce the role of brokers by providing farmers information on timber prices and fair pricing incentives, and (iii) formulate and implement a strategy for development through multistakeholder engagement.

\section{REFERENCES}

Abel T, Stepp JR. 2003. A new ecosystems ecology for anthropology. Conserv Ecol 7 (3): 12.

Andayani W. 2003. The strategy for improving business efficiency of private forest. Jurnal Hutan Rakyat 5 (3): 17-29. [Indonesian] 
Agrawal A, Cashore B, Hardin R, Shepherd G, Benson C, Miller D. 2013. Economic contributions of forests. United Nations Forum on Forests 20 March 2013. Istanbul, Turkey. Analysis of multiple forest values in Southern Ontario. For Pol Econ 6 (3-4): 215-227.

Angelsen A. 1999. Agricultural expansion and deforestation: modeling the impact of population, market forces and property rights. J Dev Econ 58: $185-218$.

BPS [Badan Pusat Statistik]. 2015. Bogor District in Figure 2015. BPS, Bogor. [Indonesian]

Birgantoro BA, Nurrochmat DR. 2007. Utilization of forest resources by communities in KPH North Banyuwangi. Jurnal Manajemen Hutan Tropika 13 (3): 172-181.[Indonesian]

Borg I, Groenen PJF. 1997. Modern Multidimensional Scaling: Theory and Applications. Springer, New York.

Chakravarty S, Ghosh SK, Suresh CP, Dey AN, Shukla G. 2012. Deforestation: Causes, Effects and Control Strategies, Global Perspectives on Sustainable Forest Management. Clement A. Okia (ed.). InTech Europe, Rijeka, Croatia.

Clarke J. 2006. Trends in Forest Ownership, Forest Resources Tenure and Institutional Arrangements: Are They Contributing to Better Forest Management and Poverty Reduction? A Case Study From South Africa. FAO, Rome.

Darusman D, Hardjanto. 2006. Economic overview of private forest. Prosiding Seminar Hasil Penelitian Hasil Hutan 2006: 4-13 Departemen Kehutanan, Jakarta. [Indonesian]

Darusman D, Wijayanto N. 2007. The economics of private forest (Funding Scheme). Studium General dalam Pekan Hutan Rakyat II di Balai Penelitian Kehutanan Ciamis, 30 Oktober 2007. [Indonesian]

DeClerck F, Ingram JC, Rumbaitis del Rio C.2006. The role of ecological theory and practice in poverty alleviation and environmental conservation. Front Ecol 4: 533-540.

DeSherbinin A, Carr D, Cassels S, Jiang L. 2007. Population and environment. Ann Rev Environ Resour 32: 5.1-5.29.

Distanhut [Dinas Pertanian dan Kehutanan Kabupaten Bogor]. 2008 Annual Report of Agriculture and Forestry: A Monograph. Office of Agriculture and Forestry Bogor District, Bogor. [Indonesian]

Distanhut [Dinas Pertanian dan Kehutanan Kabupaten Bogor]. 2012. Annual Report of Agriculture and Forestry: A Monograph. Office of Agriculture and Forestry Bogor District, Bogor. [Indonesian]

Distanhut [Dinas Pertanian dan Kehutanan Kabupaten Bogor]. 2014 Annual Report of Agriculture and Forestry: A Monograph. Office of Agriculture and Forestry Bogor District, Bogor. [Indonesian]

FAO [Food and Agriculture Organization]. 2010. Global Forest Resources Assessment 2010. FAO, Rome.

Fauzi A, Anna Z. 2005. Modeling of Fisheries and Marine Resources. Gramedia. Jakarta [Indonesian]

Febriani D, Darusman D, Nurrochmat DR, Wijayanto N. 2012. Policy implementation strategy on Community Plantation Forest in Sarolangun District, Jambi. Jurnal Analisis Kebijakan Kehutanan. 9 (2): 81-95. [Indonesian]

Groenen PJF, Terada Y. 2015. Symbolic Multidimensional Scaling (No. EI 2015-15). www.repub.eur.n1/pub/78189/EI2015-15.pdf

Groenen PJF, van de Velden M. 2004. Multidimensional Scaling. (No. EI 2004-15). www.repub.eur.nl/pub/1274/ei200415.pdf

Gunarso P, Setyawati T, Sunderland T, Shackleton C (eds.). 2007a Managing Forest Resources in a Decentralized Environment: Lessons Learnt from the Malinau Research Forest, East Kalimantan. Center for International Forestry Research (CIFOR), Bogor.

Gunarso P, Santosa KD, Shackleton C, Sunderland T, Campbell BM, Priyadi H, Levang P, Sheil D, Dounias E. 2007b. Towards Sustainable Forest Management and Improved Livelihoods In Tropical Forests: Lessons and Conclusions. CIFOR, Bogor.

Guntoro S. 2011. Time to Implement Techno-Ecological Agriculture. An Agricultural Future Model for Addressing Climate Change. PT Agromedia Pusaka, Jakarta [Indonesian]

Ingram JC, DeClerck F, Rumbaitis del Rio C (eds.). Integrating Ecology and Poverty Reduction: The Application of Ecology in Development Solutions. Springer, New York. DOI: 10.1007/978-1-4614-0186-5_6

Kant S, Wang S, Deegen P, Hostettler M, von Detten R, Howard T, Laband D, Montgomery C, Roberti N, Sekot W, Valatin G, Zhang D. 2013. New frontiers of forest economics. For Pol Econ 35: 1-8.

Kant S. 2010. Global Trends in Ownership and Tenure of Forest Resources and Timber Pricing. Professional Foresters Association, Ontario.

Kant S. 2003. Extending the boundaries of forest economics. For Pol Econ 5: $39-56$
Kant S. 2004. Economics of sustainable forest management. For Pol Econ 6: 197-203

Kant S, Berry A. 2005. Economics. Sustainability, and Natural Resources: Economics of Sustainable Forest Management. Springer, Dordrecht.

Kant S, Lee S. 2004. A social choice approach to sustainable forest management: an analysis of multiple forest values in Northwestern Ontario. For Pol Econ 6: 215-227.

Kavanagh P. 2001, Rapid Appraisal of Fisheries (Rapfish) Project: Rapfish Software Description (for Microsoft Excel). University of British Columbia, Vancouver.

Kavanagh P, Pitcher TJ. 2004. Implementing Microsoft Excel Software for Rapfish: A Technique for the Rapid Appraisal of Fisheries Status. Tech. Rept. 12 (2). Fisheries Centre Research Reports, Vancouver.

Kigenyi FW. 2007. Trends In Forest Ownership, Forest Resources Tenure And Institutional Arrangements: Are They Contributing To Better Forest Management And Poverty Reduction? A Case Study From Uganda. FAO, Rome.

Kusmana C. 2011. Forest Resources and Forestry in Indonesia. For Sci Technol 7: 4, 155-160.

Levang P. 2002. People's Dependencies on Forests. In Technical Report, Phase I 1997-2001. ITTO Project PD 12/97 Rev. 1 (F)-Forest, Science and Sustainability: The Bulungan Model Forest. CIFOR, Bogor.

Marwa J, Purnomo H, Nurrochmat DR. 2010. Managing the Last Frontier of Indonesian Forest in Papua. IPB-AKECOP Korea, Bogor.

Muttaqin MZ. 2008. Good Governance in the Five Priority Policies of the Ministry of Forestry. Jurnal Analisis Kebijakan 5 (3): 143-151. [Indonesian]

Nasi R, Frost PGH. 2009. Sustainable forest management in the tropics: is everything in order but the patient still dying? Ecol Soc (2): 40

Nurrochmat DR, Abdulah L. 2014. Utilizing forests, reducing emissions. Risalah Kebijakan Pertanian dan Lingkungan 1 (1): 18-23. [Indonesian]

Nurrochmat DR, Darusman D, Ruchjadi D. 2014. Reconstruction of the forestry tenure system. Risalah Kebijakan Pertanian dan Lingkungan 1 (1): 24-29. [Indonesian]

Plencovich MC. 2014. Voices from the forest: Integrating indigenous knowledge into sustainable upland farming. J Agric Educ Extens 20 (1): $147-149$

Pitcher TJ. 1999. Rapfish, a Rapid Appraisal Technique for Fisheries, and it Application to the Code of Conduct for Responsible Fisheries. University of British Columbia, Vancouver.

Pitcher TJ, Preiksho D. 2001. RAPFISH: a rapid appraisal technique to evaluate the sustainability status of fisheries. Fish Res 49: 255-270.

Pitcher TJ, Lam ME, Ainsworth C, Martindale A, Nakamura K, Perry RI, Ward T. 2013. Improvements to Rapfish: a rapid evaluation technique for fisheries integrating ecological and human dimensions. J Fish Biol 83: 865-889.

Prabhu R, Colfer C, Shepherd G. 1998. Criteria and Dimensions for Sustainable Forest Management: New Findings from CIFOR's Forest Management Unit Level Research. Rural Development Forestry Network, London.

Sahide MAK, Supratman S, Maryudi A, Giessen L. 2015. Forest Management Units Experimentation in Indonesia: Is it Supporting Devolution and Forest Management or Re-Centralisation? Management of land use systems for enhanced food securityconflicts, controversies and resolutions. Tropentag, September 16-18, 2015 in Berlin.

SCBD [Secretariat of the Convention on Biological Diversity]. 2009. Sustainable Forest Management, Biodiversity and Livelihoods: A Good Practice Guide. Secretariat of the Convention on Biological Diversity, Montreal

Schmithüsen F, Hirsch F. 2010. Private Forest Ownership In Europe. Geneva Timber and Forest Study Paper 26. Forestry and Timber Section, Geneva.

Schneider F, Jallis G, Martinez-Alier J. 2010. Crisis or opportunity? Economic degrowth for social equity and ecological sustainability. Introduction to this special issue. J Clean Prod 18: 511-518.

Silas SR. 2014. Reducing impact of land degradation in Tanzania: Do incentive market based mechanisms work for sustainable land management? J Sustain Dev 7 (6): 2014. DOI: 10.5539/jsd.v7n6p1

Subagyo PJ. 2006. Research Methods in Theoretical and Practical. Rineka Cipta, Jakarta. [Indonesian]

Suryawati SH, Soetarto E, Adrianto L, Purnomo AH. 2011. Identification resource management incentive systems at Laguna Segara Anakan. 
Jurnal Kebijakan Sosial Ekonomi Kelautan dan Perikanan 1 (1):[Indonesian]

UN [United Nations]. 2008. Resolution Adopted by the General Assembly 62/98: Non-legally Binding Instruments on All Types of Forests. www.daccessdds.un.org/doc/UNDOC/GEN/N07/469/65/PDF/N0746 965.pdf

Wildenberg M. 2005. Ecology, Rituals and System-Dynamics. An attempt to Model the Socio-Ecological System of Trinket Island. Social Ecology Working Paper 80. Vienna.
Wollenberg E, Edmunds D, Buck L. 2001. Anticipating Change: Scenarios for Adaptive Forest Management Facility. CIFOR, Bogor.

Wolosin M, Elias P, Riddle A, Nguyen D. 2012. Forest Interventions with Economic Returns. Issue Paper November 2012. Climate Advisers, Washington, DC.

Young FY. 2009. Multidimensional Scaling (MDS). University of North Carolina, Chapel Hill.

Zhang D, Pearse PH. 2011. Forest Economics. UBC Press, Vancouver. 